\title{
Gyrolite: its crystal structure and crystal chemistry
}

\author{
Stefano Merlino \\ Dipartimento di Scienze della Terra, Università di Pisa, Via S. Maria 53, 56100 Pisa, Italy
}

\begin{abstract}
The crystal structure of gyrolite from Qarusait, Greenland, was solved and refined with the space group $P \overline{1}$ and cell parameters $a=9.74(1), b=9.74(1), c=22.40(2) \AA, \alpha=95.7(1)^{\circ}, \beta=91.5(1)^{\circ}, \gamma=120.0(1)^{\circ}$. The structure is built up by the stacking of the structural units already found in the crystal structure of reyerite (Merlino, 1972,1988), namely tetrahedral sheets $S_{1}$ and $S_{2}$ and octahedral sheets $O$. The tetrahedral and octahedral sheets are connected by corner sharing to give rise to the complex layer which can be schematically described as $\bar{S}_{2} \bar{O} S_{1} O S_{2}$, where $S_{2}$ and $\bar{S}_{2}$, as well as $O$ and $\bar{O}$, are symmetry-related units. Successive complex layers with composition $\left[\mathrm{Ca}_{14} \mathrm{Si}_{23} \mathrm{AlO}_{60}(\mathrm{OH})_{8}\right]^{-5}$ are connected through an interlayer sheet made up by calcium and sodium cations and water molecules.

The unit cell content $\mathrm{NaCa}_{16} \mathrm{Si}_{23} \mathrm{AlO}_{60}(\mathrm{OH})_{8} \cdot 14 \mathrm{H}_{2} \mathrm{O}$, determined by the structural study, was confirmed by a chemical analysis, apart from the indication of a somewhat larger water content. The crystal chemistry of gyrolite is discussed on the basis of the present structural results and the chemical data given in the literature for gyrolite from different localities: the crystal chemical formula which accounts for most gyrolite samples is $\mathrm{Ca}_{16} \mathrm{Si}_{24} \mathrm{O}_{60}(\mathrm{OH})_{8} \cdot(14+x) \mathrm{H}_{2} \mathrm{O}$, with $0 \leqslant x \leqslant 3$.

Stacking disorder, twinning and polytypic variants in gyrolite, as well as the structural relationships of gyrolite with truscottite, reyerite, fedorite and the synthetic phases $\mathrm{K}$ and $\mathrm{Z}$ are described and discussed.
\end{abstract}

KEYWords: gyrolite, crystal structure, Qarusait, Greenland.

\section{Introduction}

GYROLITE, a hydrated calcium silicate, has long been of interest to mineralogists and chemists, particularly those concerned with the chemistry of cements, who have attempted to clarify its crystal chemistry and its relationships with reyerite and truscottite.

Gyrolite was found as a natural mineral in Skye, Scotland, by Anderson (1851) and was subsequently identified in several other localities, associated with zeolites in basalts. It was first synthesized by Flint et al. (1938) and was later prepared by other researchers: their results indicate that gyrolite is a stable phase under saturated steam conditions from $120^{\circ} \mathrm{C}$ to about $200^{\circ} \mathrm{C}$ (Taylor, 1964).

A thorough study of the crystal chemistry of gyrolite was carried out by Mackay and Taylor (1953) on samples from Bombay, India. On the basis of X-ray diffraction data, chemical analysis and dehydration studies, they indicated that gyrolite is a sheet silicate with a structure based on a hexagonal, or pseudohexagonal, structural element with $a=9.72, c=22.1 \AA$, and a chemical composition $\mathrm{Ca}_{16} \mathrm{Si}_{24} \mathrm{O}_{60}(\mathrm{OH})_{8} \cdot 12 \mathrm{H}_{2} \mathrm{O}$. They assumed that these structural elements are stacked on top of

Mineralogical Magazine, June 1988, Vol. 52, pp. 377-87 (C) Copyright the Mineralogical Society each other with successive angular displacements of $60^{\circ}$ (Mackay and Taylor, 1953), in a hexagonal unit cell with $a=9.72, c=132.8 \AA$.

Strunz and Micheelsen (1958) maintained they found a trigonal one-layer crystal of gyrolite, with $a=9.80, c=22.08 \AA$ and chemical composition $\mathrm{Ca}_{18} \mathrm{Si}_{24} \mathrm{O}_{60}(\mathrm{OH})_{12} \cdot 12 \mathrm{H}_{2} \mathrm{O}$, and Cann (1965) who studied gyrolite crystals he found associated with reyerite at Mull, suggested that 'the structure was made up of three layers of relatively low symmetry to give a trigonal structure with $a=9.76, c=$ $67.0 \AA$ ', and proposed the ideal formula $\mathrm{Ca}_{16} \mathrm{Si}_{24}$ $\mathrm{O}_{60}(\mathrm{OH})_{8} \cdot 14 \mathrm{H}_{2} \mathrm{O}$ for the content of the single layer.

The close structural relationships between gyrolite, truscottite and reyerite were postulated by Mackay and Taylor (1953) and Chalmers et al. (1964); Mayer and Jaunarajs (1961), in their work on the synthesis and crystal chemistry of gyrolite, obtained and studied intergrowths of the two phases. The kind of structural relationships which link these minerals was understood as soon as the main features of the crystal structure of reyerite were known (Merlino, 1972, 1988). Reyerite is characterized by octahedral calcium sheets $O$ and single and double sheets of silicon and aluminum 
tetrahedra, $S_{1}$ and $S_{2} \bar{S}_{2}$ respectively. The stacking of the various sheets may be described by the scheme. .. $S_{1} O S_{2} \bar{S}_{2} \bar{O} S_{1} \ldots$, with alkali cations and water molecules in the voids of the structure, which can be represented by the formula $(\mathrm{Na}, \mathrm{K})_{2} \mathrm{Ca}_{14}$ $\mathrm{Si}_{22} \mathrm{Al}_{2} \mathrm{O}_{58}(\mathrm{OH})_{8} \cdot 6 \mathrm{H}_{2} \mathrm{O}$.

Work on the structure of reyerite (Merlino, 1972) suggested a model structure for gyrolite (tested by $2800 l$ reflections), in which the $S_{2} \bar{S}_{2}$ layer in reyerite is split into two separate sheets and an unknown new layer $X$, made up of calcium cations and water molecules, is inserted in between, according to the schematic sequence $\ldots S_{1} O S_{2} X \bar{S}_{2} \bar{O} S_{1} \ldots$ Such a scheme was also suggested by $T$. Kato (pers. comm., 1972) and H. F. W. Taylor who, with Gard et al. (1975), sketched layer sequences for truscottite, gyrolite and the synthetic Assarsson's $Z$-phase, and proposed $\mathrm{Ca}_{16} \mathrm{Si}_{24} \mathrm{O}_{60}(\mathrm{OH})_{8}$. $14 \mathrm{H}_{2} \mathrm{O}$ as the crystal chemical formula for gyrolite.

Eberhard and Hamid Rahman (1982) proposed a different structural model for gyrolite, corresponding to the schematic sequence ... $\bar{O} S_{1} O S_{1} X \bar{S}_{1} \bar{O} \ldots$ and the crystal chemical formula $\mathrm{Ca}_{13}\left(\mathrm{Si}_{8} \mathrm{O}_{20}\right)_{3}$ $(\mathrm{OH})_{2} \cdot 22 \mathrm{H}_{2} \mathrm{O}$, and tested it by means of $120 h k 0$ reflections collected with an electron diffraction pattern and $2800 l \mathrm{X}$-ray diffraction spots: the number and the kind of reflections are obviously unsuited to discriminate between alternative structural models.

The poor quality of gyrolite crystals has hitherto prevented a definite proof of the claimed relationships between gyrolite, truscottite and reyerite and the determination of the exact nature of the interlayer sheet $X$.

\section{Experimental}

A large number of crystal fragments from various sources were tested by means of Weissenberg and precession photographs. The $00 l$ reflections appeared as sharp spots on the various photographs or, more frequently, as dashes, due to slight bending of the crystal flakes, and were spaced in the reciprocal space corresponding to a direct interplanar distance of $22.2 \AA$. The overall pattern indicated imperfections of various kinds, in addition to that related to the bending of the crystal plates; in fact, the diffuse streaks along $c^{*}$, as well as the distribution of sharp maxima, which sometimes appear irregularly spaced along the rows, are indicative of some disordering in the sequence of structural layers $22.2 \AA$ wide, such as twinning, domain structures with differently oriented domains and disordered stacking.

In a sample of gyrolite from Bramburg, Germany, kindly donated by E. Koritnig, a crystal fragment was found which gave a diffraction pattern of sufficient quality to permit the determination of the unit cell parameters; this showed gyrolite to be triclinic, with $a=9.72, b=9.72, c=22.50 \AA$, $\alpha=95.5^{\circ}, \quad \beta=92.0^{\circ}, \quad \gamma=120.0^{\circ}$, values quite similar to those found by Eberhard and Hamid Rahman (1982). Single crystal diffractometer data (1184 reflections collected with Mo- $K x$ radiation; $\omega-20$ scan, scan width $1^{\circ}$, scan rate $0.04^{\circ} / \mathrm{sec}$ ) were used to test the general model for gyrolite structure based on that of reyerite: they gave $R=0.20$ for 412 reflections with $F_{0} \geqslant 6 \sigma\left(F_{0}\right)$, thus indicating that the general features of the model were correct, but failed to determine the structure of the sheet $X$.

Eventually a sample from Qarusait, Greenland, kindly provided by O. V. Petersen, showed crystals of relatively good quality. One of them, carefully selected, appeared of sufficient quality for data collection with a Philips PW 1100 single crystal diffractometer, after obtaining the unit cell parameters: $a=9.74(1), b=9.74(1), c=22.40(2) \AA, \alpha=$ $95.7(1)^{\circ}, \beta=91.5(1)^{\circ}, \gamma=120.0(1)^{\circ}$. A total of 3493 independent reflections with $I \geqslant 2 \sigma(I)(\omega-2 \theta$ scan; Mo- $K \alpha$ graphite monochromatized radiation; scan width $1.4^{\circ}$; scan rate $0.04^{\circ} / \mathrm{sec}$ ) were measured in the range $2^{\circ} \leqslant \theta \leqslant 25^{\circ}$. The data were corrected for Lorentz and polarization factors; no absorption correction was applied due to the small dimensions of the crystal and the low value of the absorption coefficient.

Starting coordinates for the atoms in the complex layer $\bar{S}_{2} \bar{O} S_{1} O S_{2}$ were already obtained in the preceding stages. After two refinement cycles, a difference Fourier synthesis was calculated. It showed one prominent maximum at $z \simeq 0.5$, which was assumed to correspond to a calcium site, $\mathrm{Ca} 4$. Further maxima were cautiously introduced following the order of their heights in successive difference syntheses. The first five maxima were taken, on the basis of their heights and positions, as water molecules: four of them, $W 1$ to $W 4$, were placed around the calcium atom $\mathrm{Ca} 4$ and completed, together with two apical oxygen atoms from successive complex layers, a nearly perfect octahedral coordination, whereas $W 5$ was located at a distance from $\mathrm{Ca} 4$. A distinct peak was then observed in the special position at $0,0, \frac{1}{2}$; its height seemed to indicate it was an oxygen site, but it was too close to the $W 5$ site $(\sim 2.4 \AA)$. Two further maxima, similarly assumed to be water molecules on the basis of the peak heights, were close to the peak at $0,0, \frac{1}{2}$ and completed, together with their symmetry related counterparts and two symmetry related $W 5$ water molecules, a fairly regular octahedral coordination around it; the octahedral coordination, the values of the bond distances to the ligands and the peak height pointed to a partial 
occupancy by calcium or full occupancy by sodium cations of this site.

In the stage just described cycles of least squares refinements were alternated with difference syntheses. Once the construction of the structure was completed, a few more cycles were carried out. In these last cycles common thermal parameters were attributed to calcium, silicon and oxygen atoms of the complex layer: the thermal parameters refined to the very low $\mathrm{B}$ values $0.03,0.04,0.05 \AA^{2}$ for calcium, silicon and oxygen respectively. In the case of the cations and water molecules in the interlayer sheet, not only the positional but also the thermal parameters were allowed to vary independently.
Unit weights and atomic scattering factors for neutral atoms (Cromer and Mann, 1968) were used throughout. The conventional residual index for 3259 reflections with $F_{0} \geqslant 5 \sigma\left(F_{0}\right)$ was $R=0.135$. Observed and calculated structure factors are listed in Table $1{ }^{*}$ whereas Table 2 gives the final atomic parameters.

Although the final $R$ value gives full confidence in the correctness of the structure, the high $B$ parameters of the atoms in the interlayer sheet, together with the low $B$ parameters of the atoms in the complex layer, give indication of an appreciable

* Table 1 is deposited in the Mineralogy Library at the British Museum (Natural History).

TABLE 2. Atomic coordinates in the complex layer (e,s.d,s for $x$ and $\underline{x}$ coordinates are $0.0006,0.0008$ and 0,0020 for calciun silicon and oxygen respectively, whereas those for z coordinates are $0.0002,0.0003$ and 0,0008 respectively) and in the interlayer sheet (e.s.d.s in parentheses). The names of the atoms in the complex layer are given with reference to those of the corresponding atoms in reyerite; for example, $\mathrm{Ca} 20$, Ca21 and Ca22 correspond to $\mathrm{Ca} 2$ in reyerite.

\begin{tabular}{|c|c|c|c|c|c|c|c|}
\hline Atom & $x$ & $y$ & $z$ & Atom & $x$ & $y$ & $z$ \\
\hline Calo & 0.7048 & 0.3902 & 0.1673 & 032 & 0.3234 & 0.9359 & 0.2096 \\
\hline Ca2O & 0.2762 & 0.1014 & 0.1446 & 040 & 0.4659 & 0.3420 & 0.2138 \\
\hline $\mathrm{Ca} 21$ & -0.0176 & 0.2425 & 0.1448 & 041 & 0.7770 & 0.2193 & 0.2130 \\
\hline Ca22 & -0.1596 & -0.1941 & 0.1447 & 042 & 0.8981 & 0.6557 & 0.2126 \\
\hline $\mathrm{Ca} 30$ & 0.4259 & 0.5357 & 0.7684 & 050 & 0.0400 & 0.0638 & 0.1878 \\
\hline Ca31 & -0.4387 & -0.0311 & 0.1682 & 060 & 0.3617 & 0.7079 & 0.1205 \\
\hline $\mathrm{Ca} 32$ & 0.1281 & -0.3299 & 0.1674 & 070 & 0.2541 & 0.2287 & -0.0207 \\
\hline Si10 & 0.2193 & 0.3284 & 0.0331 & 071 & 0.2418 & 0.9794 & 0.0202 \\
\hline Sill & 0.3086 & 0.0952 & -0.0329 & 072 & 0.0295 & 0.2660 & 0.0202 \\
\hline $5 i 12$ & 0.1130 & 0.8012 & 0.0328 & 080 & 0.3280 & 0.5155 & 0.0216 \\
\hline Si20 & 0.3447 & 0.6838 & 0.0485 & 081 & 0.4959 & 0.8188 & 0.0230 \\
\hline si 30 & 0.4267 & 0.3319 & 0.2829 & 082 & 0.1921 & 0.6884 & 0.0214 \\
\hline $5 i 31$ & 0.8238 & 0.2215 & 0.2831 & 090 & 0.3011 & 0.3917 & 0.2985 \\
\hline $5 i 32$ & 0.9367 & 0.7301 & 0.2818 & 091 & 0.7700 & 1.0424 & 0.2996 \\
\hline Si 40 & 0.1873 & 0.4602 & 0.2820 & 092 & 1.1205 & 0.8575 & 0.2955 \\
\hline Si41 & 0.6996 & 0.8544 & 0.2808 & 0100 & 0.3400 & 1.1518 & 0.2994 \\
\hline $5 i 42$ & 0.3056 & 0.9699 & 0.2800 & 0101 & 1.0175 & 0.3269 & 0.2999 \\
\hline Si50 & 0.7461 & 0.4528 & 0.3557 & 0102 & 0.8543 & 0.8299 & 0.2985 \\
\hline si60 & 0.4169 & 0.7889 & 0.3576 & 0110 & 0.4366 & 0.8193 & 0.4241 \\
\hline 010 & 0.2416 & 0.3011 & 0.1008 & 0111 & 0.7686 & 0.4817 & 0.4268 \\
\hline 11 & 0.2372 & 0.0092 & -0.0999 & 0120 & 0.2440 & 0.6236 & 0.3252 \\
\hline 012 & 0.0663 & 0.8143 & 0.1002 & 0121 & 0.5620 & 0.7669 & 0.3239 \\
\hline 020 & 0.5166 & 0.1380 & 0.1165 & 0122 & 0.4212 & 0.9385 & 0.3214 \\
\hline 021 & -0.0717 & 0.4364 & 0.1164 & 0130 & 0.5802 & 0.4380 & 0.3304 \\
\hline 022 & -0.3671 & -0.4522 & 0.1160 & 0131 & 0.7402 & 0.2870 & 0.3271 \\
\hline 030 & 0.1851 & 0.4871 & 0.2127 & 0132 & 0.8904 & 0.5970 & 0.3246 \\
\hline 031 & 0.6391 & 0.7963 & 0.2100 & & & & \\
\hline
\end{tabular}

Atoms in the interlayer sheet.

\begin{tabular}{|c|c|c|c|c|}
\hline Atom & $x$ & $y$ & $z$ & $B\left(A^{2}\right)$ \\
\hline Ca4 & $0.3302(11)$ & $0.6718(11)$ & $0.4983(4)$ & $4.1\{0.2\}$ \\
\hline WT & $0.2919(53)$ & $0.8740(52)$ & 0.5464 (21) & $8.7(1.1)$ \\
\hline W2 & $0.0784(49)$ & $0.5475 \quad(48)$ & $0.4391(20)$ & $8.0(1.1)$ \\
\hline W3 & $0.3937 \quad(66)$ & $0.4892(67)$ & $0.4478(28)$ & $12.0(1.7)$ \\
\hline W4 & $0.5877 \quad(69)$ & $0.8303(69)$ & $0.5582(29)$ & $12.6(1.7)$ \\
\hline $\mathrm{Na}$ & 0 & 0 & $1 / 2$ & $13.7(2.7)$ \\
\hline W5 & $0.7684(77)$ & $0.7748(77)$ & $0.4422(33)$ & $15.0(2.4)$ \\
\hline W6 & $0.9470(97)$ & $0.8255(98)$ & 0.5864 (44) & $16.3(2.5)$ \\
\hline w7 & $0.8687(96)$ & $1.1174(96)$ & $0.5489(40)$ & $15.6 \quad(2.5)$ \\
\hline
\end{tabular}


degree of disorder. Moreover the disordered nature of gyrolite was quite evident from the examination of the final difference Fourier synthesis, which showed four quite distinct maxima. Two of them, together with $\mathrm{Ca} 4$ site, build up a triplet around the apical oxygen atom 0110 ; the other two maxima, together with the calcium site $\mathrm{Ca}^{i}$, symmetry related to $\mathrm{Ca} 4$ through the inversion centre at $\frac{1}{2}, \frac{1}{2}, \frac{1}{2}$, build up a similar triplet around the apical oxygen atom 0111 . These triplets were indicative, as will be discussed in a further section, of disorder in the stacking of the structural layers; this was already evident from the Weissenberg photographs. The disorder in the layer stacking accounts for the relatively high $R$ value, which thus appears quite satisfactory.
Description and discussion of the structure

The crystal structure of gyrolite is built up by the stacking of various structural layers:

(1) a centrosymmetrical layer $S_{1}$, characterized by six-membered rings of tetrahedra pointing alternately upwards and downwards and described in the paper on the structure of reyerite (Merlino, 1988, Fig. 1);

(2) an octahedral sheet $O$ of edge-sharing calcium octahedra;

(3) a tetrahedral sheet $S_{2}$, characterized, as $S_{1}$, by six-membered rings, but presenting six downwardpointing tetrahedra to every two upward-pointing tetrahedra: it is described in the paper on the structure of reyerite (Merlino, 1988, Fig. 2).

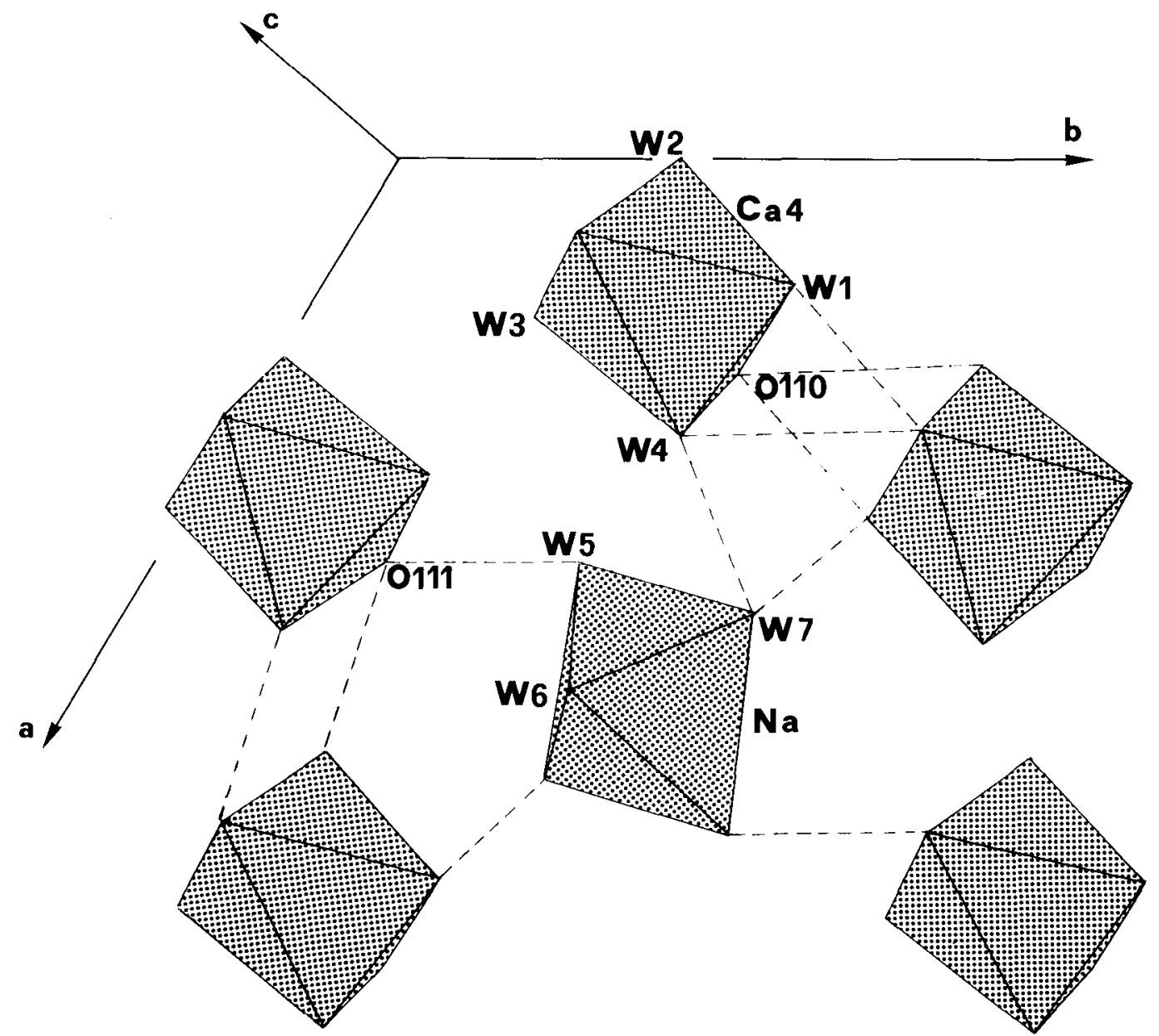

Fig. 1. Projection along $c^{*}$ of the crystal structure of the interlayer sheet $X$. The figure shows the coordination octahedra around $\mathrm{Ca} 4$ and $\mathrm{Na} .0110$ and 0111 are the apical oxygen atoms of the Si60 and Si50 tetrahedra in the $S_{2}$ layer. Hydrogen bonds are indicated by dashed lines. W indicates water molecules. 
The tetrahedral and octahedral sheets are connected by corner sharing (Merlino, 1988, Figs. 1 and 2) to give rise to the complex layer which can be schematically described as $\bar{S}_{2} \bar{O} S_{1} O S_{2}$, where $S_{2}$ and $\bar{S}_{2}$, as well as $O$ and $\bar{O}$, are symmetry-related structural units. Successive complex layers are connected through

(4) an interlayer sheet $X$ made up by calcium and sodium octahedra (Fig. 1).

Tetrahedral and octahedral sheets. Tetrahedral and octahedral sheets were already described and represented in the paper on the crystal structure of reyerite (Merlino, 1988). It may simply be recalled here that both $S_{1}$ and $S_{2}$ have composition $\left[\mathrm{Si}_{8} \mathrm{O}_{20}\right]^{-8}$; the composition of the octahedral sheet is $\left[\mathrm{Ca}_{7} \mathrm{O}_{10}(\mathrm{OH})_{4}\right]^{-4}$. The $\mathrm{Si}-\mathrm{O}$ and $\mathrm{Ca}-\mathrm{O}$ bond lengths in these sheets are given in Table 3. As in the crystal structure of reyerite, each calcium cation is octahedrally coordinated by oxygen atoms and hydroxyl anions, with quite regular bond lengths ranging from a minimum of $2.28 \AA$ to a maximum of $2.57 \AA$; $\mathrm{Ca} 20, \mathrm{Ca} 21$ and $\mathrm{Ca} 22$, which correspond to $\mathrm{Ca} 2$ in reyerite, present another weak interaction with O71 (2.86 $\AA)$, O $72(2.86 \AA)$ and $\mathrm{O} 70(2.84 \AA)$ respectively.

Complex layer. Two centrosymmetrically-related octahedral sheets $O$ and $\bar{O}$ are present in the unit cell, both sandwiched between two tetrahedral sheets of different kind. The stacking sequence can be conveniently represented by the scheme $\bar{S}_{2} \bar{O} S_{1} O S_{2}$ : this complex layer has ideal chemical composition $\left[\mathrm{Ca}_{14} \mathrm{Si}_{24} \mathrm{O}_{60}(\mathrm{OH})_{8}\right]^{-4}$. It displays trigonal symmetry, although that symmetry is not preserved in the whole structure and does not appear as crystallographic symmetry. At the outskirts of the complex layer there are O110, O111 and their inversion-related counterparts. They are the apical oxygen atoms in Si50 and Si60 tetrahedra and fasten together successive layers through the interlayer sheet.

Interlayer sheet. Two symmetry-related calcium octahedra and one sodium octahedron occur in the sheet. Two apical oxygen atoms of two successive complex layers lie at opposite corners of each calcium octahedron, the octahedral coordination being completed by four water molecules. The sodium cation at the centre of symmetry at $0,0, \frac{1}{2}$ is coordinated by three pairs of symmetry-related water molecules.

Two strong hydrogen bonds reach the O111 apical oxygen, whereas one strong hydrogen bond reaches O110 apical oxygen. They are indicated in Fig. 1, together with the $W \ldots W$ hydrogen bonds corresponding to distances shorter than $3.0 \AA$. The bond lengths in the calcium and sodium octahedra and the interatomic distances of the hydrogen bonds indicated in Fig. 1 are given in Table 3.

\section{Crystal chemistry of gyrolite}

Gyrolite is a new example, after reyerite, of a silicate with two distinct kinds of tetrahedral sheet. A general view of the structure, showing the interconnections of the various building blocks, is given in Fig. 2. It was previously said that the complex layer has ideal composition $\left[\mathrm{Ca}_{14}\right.$ $\left.\left(\mathrm{Si}_{8} \mathrm{O}_{20}\right)\left(\mathrm{Si}_{8} \mathrm{O}_{20}\right)_{2}(\mathrm{OH})_{8}\right]^{-4}$ or more compactly $\left[\mathrm{Ca}_{14} \mathrm{Si}_{24} \mathrm{O}_{60}(\mathrm{OH})_{8}\right]^{-4}$. As the structure analysis indicates one sodium and two calcium cations, together with fourteen water molecules, in the interlayer sheet, charge balance may be obtained by assuming a small substitution of silicon by aluminum. Therefore the unit cell content indicated by the structure analysis for gyrolite from Qarusait is: $\mathrm{NaCa}_{16} \mathrm{Si}_{24} \mathrm{AlO}_{60}(\mathrm{OH})_{8} \cdot 14 \mathrm{H}_{2} \mathrm{O}$.

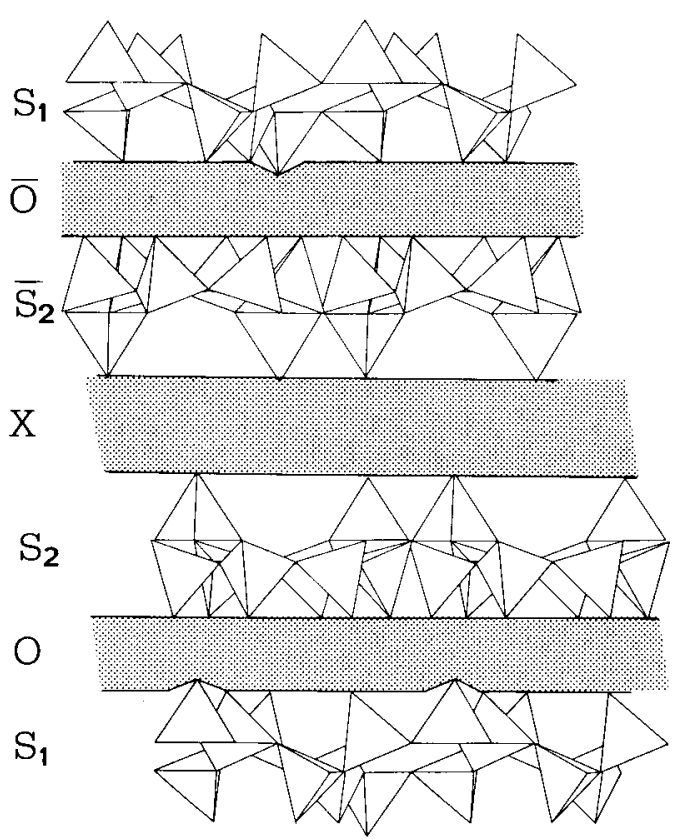

FIG. 2. Schematic drawing of the crystal structure of gyrolite as viewed along $a$.

A chemical analysis was carried out on the sample. $\mathrm{Na}_{2} \mathrm{O}$ and $\mathrm{MgO}$ were determined by atomic absorption spectrometry and $\mathrm{H}_{2} \mathrm{O}$ was determined by the weight loss on heating. On the 
$\mathrm{TA} \mathrm{BLE}$ 3. Si-O and $\mathrm{Ca}-\mathrm{O}$ bond lengths, in $\mathrm{A}$, in the complex layer (estimated standard deviations are in the range 0.015-0.020 $A$ ) and bond lengths (e.s.d.s in parentheses) and hydrogen bond distances, in $A$, in the interlayer sheet.

$$
\text { Si-0 and } \mathrm{Ca}-0 \text { bonds in the complex layer }
$$

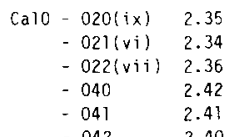

basis of the known quantities of the other elements, $\mathrm{CaO}, \mathrm{SiO}_{2}, \mathrm{Al}_{2} \mathrm{O}_{3}$ and $\mathrm{Fe}_{2} \mathrm{O}_{3}$ were determined by the X-ray fluorescence method developed by Franzini and Leoni (1972) and modified by Leoni and Saitta (1973), assuming that the sum of the weight percentages was 100 . The chemical data are reported in Table 4, column 12, together with the unit cell contents calculated on the basis of 24 
T A B LE 4. Gyrolite from various natural sources: chemical analyses and calculated unit cell contents.

\begin{tabular}{|c|c|c|c|c|c|c|c|c|c|c|c|c|c|c|c|c|c|}
\hline & 1 & 2 & 3 & 4 & 3 & 6 & 7 & $y$ & y & 10 & 11 & 12 & 13 & 14 & 15 & 16 & 17 \\
\hline $\mathrm{SiO}_{2}$ & 50.70 & 51.90 & 52.54 & 52.09 & 50.23 & 50.0 & 50.60 & 48.62 & 51.06 & 52.97 & 52.28 & 50.88 & 53.47 & 52.77 & 48.88 & 51.55 & 50.19 \\
\hline $\mathrm{Al}_{2} \mathrm{G}_{3}$ & 1.48 & 1.27 & 0.71 & 0.49 & 2.19 & 3.5 & 5.54 & 4.20 & 3.04 & 1.01 & & 1.75 & 0.22 & 0.73 & 4.18 & 1.85 & 3.14 \\
\hline $\mathrm{Fe}_{2}^{2} \mathrm{O}_{3}^{3}$ & & & & & 0.20 & 0.1 & 0.41 & & 0.11 & 0.04 & & 0.25 & & & & 1.71 & 0.14 \\
\hline $\mathrm{MgO}^{3}$ & 0.18 & 0.08 & & 0.29 & 0.13 & $t_{T}$ & 1.98 & 3.73 & 0.10 & 0.12 & & 0.74 & & & 0.48 & 0.72 & 0.02 \\
\hline $\mathrm{CaO}$ & 32.24 & 29.95 & 29.97 & 33.07 & 34.04 & 32.3 & 28.54 & 27.34 & 33.07 & 32.90 & 32.67 & 31.34 & 32.00 & 33.04 & 37.45 & 30.09 & $\begin{array}{l}3 \\
3\end{array}$ \\
\hline $\mathrm{Na}_{2} \mathrm{O}$ & & & 0.27 & 0.51 & & 0.8 & 0.67 & 0.39 & 0.36 & & 1.00 & 1.34 & 1.25 & 0.35 & & 0.94 & 0.66 \\
\hline$k_{2} \delta$ & & 1.60 & 1.56 & 0.01 & & 0.2 & 0.35 & 0.22 & 0.21 & & 0.05 & & & 0.41 & & & 0.12 \\
\hline $\mathrm{H}_{2}^{2} \mathrm{O}$ & 14.18 & 15.05 & 14.60 & 13.35 & 11.98 & 13.1 & 12.34 & 16.12 & 11.27 & 12.53 & 14.45 & 13.68 & 13.21 & 12.58 & 8.67 & 12.69 & $\begin{array}{ll}8 & 13.23\end{array}$ \\
\hline & 1 & 2 & 3 & 4 & 5 & 6 & 7 & 8 & 9 & 10 & 11 & 12 & 13 & 14 & 15 & 16 & 17 \\
\hline Si & 23.20 & 23.32 & 23.62 & 23.74 & 22.83 & 22.17 & 32.04 & 21.78 & 22.43 & 23.47 & 24.00 & 23.07 & 23.88 & 23.62 & 21.80 & 23.03 & 22.35 \\
\hline $\mathrm{Al}$ & 0.80 & 0.68 & 0.38 & 0.26 & 1.17 & 1.83 & 2.84 & 2.22 & 1.57 & 0.53 & & 0.93 & 0.12 & 0.38 & 2.20 & 0.97 & 1.65 \\
\hline $\mathrm{Fe}$ & & & & & 0.07 & 0.03 & 0.14 & & 0.04 & 0.01 & & 0.08 & & & & 0.64 & 0.07 \\
\hline $\mathrm{Mg}$ & 0.12 & 0.05 & & 0.19 & 0.08 & & 1.28 & 2.49 & 0.07 & 0.08 & & 0.50 & & & 0.32 & 0.48 & 0.01 \\
\hline $\mathrm{Ca}$ & 15.80 & 14.42 & 14.44 & 16.15 & 15.99 & 15.35 & 13.32 & 13.12 & 15.56 & 15.62 & 16.07 & 15.22 & 15.32 & 15.84 & 17.90 & 14.40 & 15.51 \\
\hline $\mathrm{Ha}$ & & & 0.24 & 0.45 & $0.1 ?$ & 0.07 & 0.57 & 0.34 & 0.31 & 0.40 & 0.89 & 1.18 & 1.08 & 0.30 & & 0.81 & 0.61 \\
\hline$x$ & & 0.92 & 0.89 & & & 0.01 & 0.19 & 0.13 & 0.12 & & 0.03 & & & 0.23 & & & \\
\hline M & 15.92 & 15.39 & 15.57 & 16.79 & 16.26 & 15.46 & 16.38 & 16.08 & 16.10 & 16.11 & 16.99 & 16.98 & 16.40 & 16.37 & 18.22 & 16.33 & 16.20 \\
\hline 0 & 60.00 & 60.00 & 60.00 & 60.00 & 60.00 & 60.00 & 60.00 & 60.00 & 60.00 & 60.00 & 60.00 & 60.00 & 60.00 & 60.00 & 60.00 & 60.00 & 60.00 \\
\hline $\mathrm{OH}$ & 7.04 & 5.18 & 4.70 & 8.00 & 7.30 & 5.04 & 7.06 & 5.50 & 6.24 & 7.30 & 8.00 & 7.92 & 7.60 & 7.84 & 8.00 & 6.88 & 6.14 \\
\hline $\mathrm{H}_{2} \mathrm{O}$ & 0.96 & 2.82 & 2.38 & & 0.70 & 2.94 & 0.94 & 2.50 & 1.76 & 0.70 & & 0.08 & 0.40 & 0.16 & & 1.12 & 1.86 \\
\hline $\mathrm{OH}$ & & & & 0.88 & & & & & & & 1.05 & & & & 2.24 & & \\
\hline $\mathrm{H}_{2} \mathrm{O}$ & 17.16 & 17.14 & 17.17 & 15.85 & 13.76 & 13.89 & 13.45 & 18.83 & 11.63 & 14.17 & 17.66 & 16.64 & 15.68 & 14.70 & 7.78 & 14.35 & 14.67 \\
\hline \multicolumn{9}{|c|}{$\begin{array}{l}\text { 1. Portree (Skye), U.K. (Anderson, 1851) } \\
\text { 2. Port George (Nova Scotia), Canada (How, 1861) } \\
\text { 3. New Almaden (California), U.S.A., (Clarke, 1889): F } \\
\text { 4. Bombay, India (Christie, 1925) } \\
\text { 5. Bombay, India (Mackay and Taylor, (952; Mc Connell } \\
\text { 6. Portree (Skye), U.K. (Sweet, 196); Bothwell analyst } \\
\text { 7. SAirde Beinn (Mull), U.K. (Cann, 1965) } \\
\text { 8. Monte Biaena, Italy (Gottardi and Passaglia, 1967) } \\
\text { 9. Irakawa (Yamagata Prefecture), Japan (Mizota, 1969) }\end{array}$} & \multicolumn{9}{|c|}{$\begin{array}{l}\text { 10. Lower Tunguska river, U.S.S.R. (Kudriashova, 1958) } \\
\text { 11. Sewree (Bombay), India (Sukheswala et al., 1974) } \\
\text { 12. Qarusat, Greenland (present work) } \\
\text { 13. Fort Point (California), U.S.A. (Schaller, 1905) } \\
\text { 14. Mogy Guassu', Brasil (Hussak, 906; Florence analyst) } \\
\text { 15. Sayamlake, Japan (Kobayashi and Kawai, 1974) } \\
\text { 16. Ortano (Elba), Italy (Garavelli and Vurro, 1984) } \\
\text { 17. Arsului and Korit valleys, Rumania (Istrate and Anton, }\end{array}$} \\
\hline
\end{tabular}

$(\mathrm{Si}+\mathrm{Al})$ atoms. The results indicate the following chemical formula:

$\left(\mathrm{Na}_{1.18} \mathrm{Ca}_{15.22} \mathrm{Mg}_{0.50} \mathrm{Fe}_{0.08}\right)_{\Sigma 16.98}$

$$
\left(\mathrm{Si}_{23.07} \mathrm{Al}_{0.93}\right)_{\Sigma 24.00} \mathrm{O}_{60}(\mathrm{OH})_{7.92} \cdot 16.7 \mathrm{H}_{2} \mathrm{O} \text {. }
$$

It matches exceedingly well that obtained from the structure analysis and confirms the presence of one sodium cation in the interlayer sheet. The larger water content indicated by the chemical analysis may be reconciled with the structural results assuming that a few further water molecules can be distributed with partial occupancies among various sites in the interlayer sheet. A small maximum was indeed observed, in the last difference synthesis, at $0.02,0.28, \frac{1}{2}$, well removed from the other water sites.

Table 4 presents chemical analyses of natural gyrolites, published over a period of 140 years, disregarding those which had weight percentage sums lower than 99.5 , the only exceptions being analysis 1 , reported in the original description of gyrolite (Anderson, 1851), and those which appeared incomplete for the absence of aluminum.
Although aluminum is not essential to the structure (Al-free and $\mathrm{Na}$-free gyrolites have indeed been synthesized), it seems improbable that in natural gyrolites no aluminum at all substitutes for silicon, and the absence of aluminum in the chemical data may indicate an incomplete analysis. However, analysis 11 has been included, because it appears from Sukheswala et al. (1974) that the gyrolite samples were analysed for aluminum.

The unit cell contents, reported also in Table 4, were calculated on the basis of $24(\mathrm{Si}+\mathrm{Al})$, apart from gyrolite from 'S Airde Beinn, which presented a very high aluminum content; in that case the unit cell contents calculated by Cann (1965) from the cell dimensions and measured density were assumed. The unit cell contents were then interpreted in the light of the structural results; accordingly the last six rows list the number of: (i) octahedral cations $M$; (ii) oxygen anions; (iii) and (iv) hydroxyl anions, and possibly water molecules, in the octahedral sheet; (v) and (vi) water molecules, and possibly hydroxyl anions, in the interlayer sheet.

The number of octahedral cations is, with one 
major exception, between 15.5 and 17.0. The water content is different in gyrolite from various sources, but the data in Table 4 indicate the presence of at least fourteen molecules in the interlayer sheet, with the possible exception of gyrolite from Irakawa (Mizota, 1969), for which a water content of nearly twelve molecules was calculated, and the noteworthy exception of gyrolite from Sayama Lake (Kobayashi and Kawai, 1974), which, because of its very low water content and very high calcium content, deserves further study.

A comprehensive chemical formula for gyrolite may thus be expressed as follows:

$(\mathrm{Ca}, \mathrm{Na}, \mathrm{Mg}, \mathrm{Fe}, \square)_{17}(\mathrm{Si}, \mathrm{Al})_{24} \mathrm{O}_{60}$

$$
\left(\mathrm{OH}, \mathrm{H}_{2} \mathrm{O}\right)_{8} \cdot(14+x) \mathrm{H}_{2} \mathrm{O} \text {. }
$$

However most gyrolite samples are quite well accounted for by the simpler crystal chemical formula:

$$
\begin{array}{r}
{\left[\mathrm{Ca}_{14}\left(\mathrm{Si}_{8} \mathrm{O}_{20}\right)\left(\mathrm{Si}_{8} \mathrm{O}_{20}\right)_{2}(\mathrm{OH})_{8}\right]^{-4}} \\
{\left[\mathrm{Ca}_{2}\left(\mathrm{H}_{2} \mathrm{O}\right)_{8} \cdot(6+x) \mathrm{H}_{2} \mathrm{O}\right]^{+4}}
\end{array}
$$

or, more compactly, by the formula

$$
\mathrm{Ca}_{16} \mathrm{Si}_{24} \mathrm{O}_{60}(\mathrm{OH})_{8} \cdot(14+x) \mathrm{H}_{2} \mathrm{O}
$$

with minor substitutions of sodium and aluminum in calcium and silicon sites respectively and water molecules in hydroxyl sites.

The results of the dehydration study by Mackay and Taylor (1953), who showed that water is lost in two stages - loss of water molecules and hydroxyl anions respectively - are in keeping with the present structural results. Recently an accurate thermogravimetric study was carried out by Garavelli and Vurro (1984) on samples from Ortano (Italy) and Bombay: the results were interpreted by the authors on the basis of the present structural study.

\section{Stacking disorder, twinning and polytypism}

The complex layers $\left[\mathrm{Ca}_{14} \mathrm{Si}_{24} \mathrm{O}_{60}(\mathrm{OH})_{8}\right]^{-4}$, which in gyrolite are linked through the connection of the interlayer sheet, have trigonal symmetry. Because of this symmetry there are three possible orientations of the interlayer sheet and consequently three possible stacking vectors, related by $120^{\circ}$ rotations and with module $c$, which connect succeeding complex layers: these vectors may be conveniently called $t_{1}, t_{2}, t_{3}$. When one single stacking vector, say $\mathbf{t}_{1}$, is repeated throughout, a fully ordered one-layer triclinic structure is obtained; otherwise triclinic domains in three different orientations follow each other. In fact, a number of gyrolite crystals are made up by random successions of triclinic domains in three orientations and of different thicknesses. Accordingly their diffrac- tion patterns show, beside diffuse streaks parallel to $c^{*}$, sharp maxima corresponding to the three distinct reciprocal lattices. When few stacking faults connect large triclinic domains, the sharp spots prevail and we may more conveniently speak of twinned crystals. For example the sequence $\ldots \mathbf{t}_{1} \mathbf{t}_{1} \mathbf{t}_{1} \mathbf{t}_{1} \mathbf{t}_{2} \mathbf{t}_{2} \mathbf{t}_{2} \mathbf{t}_{2} \ldots$ corresponds to a twinned crystal with the two individuals related by a $120^{\circ}$ rotation about an axis normal to (001).

The crystal fragment used in the present structural study gave a diffraction pattern which showed the presence of a large triclinic block, although some diffuse streaks and additional spots indicated that small volumes of two other individuals in twin relationships with the preceding one, through rotations of $120^{\circ}$ and $240^{\circ}$ about an axis normal to (001), were also present. As previously stated, noteworthy features of the difference synthesis were two triplets of maxima around $\mathrm{O} 110$ and $\mathrm{O} 111$. Each triplet consisted of a large peak and two small peaks: the two large peaks correspond to the positions of the interlayer calcium cations in the largely developed block, whereas the four small peaks correspond to the positions of the interlayer calcium cations in the smaller twin-related crystal blocks.

The possibility of polytypism in gyrolite was implied by Mackay and Taylor (1953), who showed that gyrolite has a layer structure and emphasized its similarity with micas and clay minerals. Strunz and Micheelsen (1958), and subsequently Cann (1964), claimed to have found one-layer trigonal gyrolite and three-layer trigonal gyrolite respectively, in contrast to the six-layer hexagonal gyrolite studied by Mackay and Taylor (1953). Although the one-layer trigonal gyrolite is most probably one-layer triclinic gyrolite, and the diffraction patterns which seemed indicative of three-layer and six-layer gyrolites can be reinterpreted as indicative of disordered sequences of crystal blocks corresponding to the three possible stacking vectors, polytypism in gyrolite is worthy of consideration. In addition to $t_{1} t_{1} t_{1} \ldots$, ordered $t_{1} t_{2} t_{1} t_{2} \ldots$ or $\mathbf{t}_{1} \mathbf{t}_{2} \mathbf{t}_{3} \mathbf{t}_{1} \mathbf{t}_{2} \mathbf{t}_{3}$. . . sequences (trigonal, $c=67 \AA$ ) correspond to the simplest possible polytypic sequences in gyrolite: an electron microscopy study on specimens from various sources could be most fruitful.

It seems worthwhile to observe that all the ordered and disordered sequences belong to one family of OD-structures (Dornberger-Schiff, 1956, 1966) consisting of equivalent layers: in every member of the family, pairs of adjacent layers are equivalent. The ordered sequences $t_{1} t_{1} t_{1} \ldots$. , $t_{1} t_{2} t_{1} t_{2} \ldots, t_{1} t_{2} t_{3} t_{1} t_{2} t_{3} \ldots$ are the members of maximum degree of order, MDO members in the terminology of the OD theory: in those members 
not only pairs, but triples, quadruples, etc. are equivalent.

So far, the stacking disorder and polytypism have been considered only in relation to the three possible stackings of two successive complex layers across the interlayer sheet. However, it cannot be excluded that, as in other layer silicates, such as micas, zussmanite, stilpnomelane or pyrosmalite, disorder may also be related to the various possible displacements of the tetrahedral sheets which lie on either side of the octahedral component. In other words, a further cause of disorder could lie inside the complex layer. In contrast to the layer silicates just mentioned, in gyrolite the tetrahedral sheets lying on opposite sides of the octahedral sheet are different in nature.

\section{Related structures}

The basic structural relationships between reyerite, truscottite and gyrolite were mentioned in the introduction and are clearly described by Gard $e t$ al. (1975). Table 5 gives the structural schemes for the various phases in terms of the structural units: the tetrahedral sheets $S_{1}$ and $S_{2}$, the octahedral sheet $O$ and the interlayer sheet $X$, whose chemical constitution and structural features were derived in the present work.

The structures of reyerite and truscottite are very similar: reyerite (Merlino, 1972, 1988) is characterized by the presence of two ordered aluminum cations in the double tetrahedral sheet, with alkali cations and water molecules in the voids of the structure inside the double sheet; Lachowski et al. (1979) conclusively demonstrated by X-ray powder diffraction and analytical electron microscopy studies that, in the absence of substitutions, the formula of truscottite is $\mathrm{Ca}_{14} \mathrm{Si}_{24} \mathrm{O}_{58}(\mathrm{OH})_{8} \cdot 2 \mathrm{H}_{2} \mathrm{O}$, which compares with that of reyerite $(\mathrm{Na}, \mathrm{K})_{2} \mathrm{Ca}_{14}$ $\left(\mathrm{Si}_{22} \mathrm{Al}_{2}\right) \mathrm{O}_{58}(\mathrm{OH})_{8} \cdot 6 \mathrm{H}_{2} \mathrm{O}$. Truscottite thus appears, from the synthetic standpoint, as the counterpart of reyerite, obtained when aluminum and alkali cations are absent: however it can also accommodate some aluminum, with an increase in the $c$ parameter, as well as potassium cations, thus approaching the composition of reyerite (Lachowski et al., 1979). The formation of gyrolite-truscottite intergrowths (Meyer and Jaunarajs, 1961; Harker, 1964; Lachowski et al., 1979) is quite in keeping with the close structural relationships between the two phases.

Some specimens of gyrolite could probably also contain small amounts of the Z-phase as an intergrown impurity (Assarsson, 1957; Taylor, 1962). The Z-phase was obtained by Funk and Thilo (1955) by autoclaving a calcium silicate hydrated gel at $180^{\circ} \mathrm{C}$; by Assarsson (1957) by autoclaving mixtures of lime and amorphous silica at 140 $240^{\circ} \mathrm{C}$ and later by Harker (1964) by autoclaving a mixture of lime and silicic acid at $195^{\circ} \mathrm{C}$. Gard et al. (1975) showed that the Z-phase could be produced by the decomposition of Al-substituted tobermorite and they presented results of thermal, electron diffraction and infrared studies which confirmed the relationship to gyrolite.

In the preparations of Gard et al. (1975), the $Z$-phase was never obtained free from tobermorite. The highest content of the Z-phase was obtained from a one-year run: the X-ray diffraction pattern of the product showed the Z-phase with only a little tobermorite, and the results of the chemical analysis on that product are reported in Table 6 , together with the unit-cell contents, as indicated by the structural scheme in Table 5. As the interlayer sheet $X$ has composition $\left[\mathrm{Ca}_{2} \cdot(14+x) \mathrm{H}_{2} \mathrm{O}\right]^{+4}$, the ideal formula $\mathrm{Ca}_{9} \mathrm{Si}_{16} \mathrm{O}_{40}(\mathrm{OH})_{2} \cdot(14+x) \mathrm{H}_{2} \mathrm{O}$

TA B LE 5. Structural schemes, crystal chemical formulae and unit cell parameters for the various natural and synthetic phases containing the structural units $S_{1}, S_{2}, O$ and $X$.

\begin{tabular}{|c|c|c|c|c|c|c|c|c|c|}
\hline $\begin{array}{l}\text { Structura } 1 \\
\text { scheme }\end{array}$ & Phase & Crystal chemical formula & $\begin{array}{l}\text { Space } \\
\text { group }\end{array}$ & $\mathrm{a}(\ddot{A})$ & $\mathrm{b}(\mathrm{A})$ & $\begin{array}{l}\text { Cell parame } \\
\text { C(A) }\end{array}$ & $\begin{array}{l}\text { eters } \\
\qquad a\end{array}$ & $\beta$ & $\gamma$ \\
\hline \multirow{2}{*}{$\mathrm{s}_{1} \mathrm{OS} \mathrm{S}_{2} \overline{\mathrm{s}}_{2} \overrightarrow{\mathrm{S}}_{1}$} & reyerite & $(\mathrm{Na}, \mathrm{K})_{2} \mathrm{Ca}{ }_{14} \mathrm{Si}_{22} \mathrm{Al}_{2} \mathrm{O}_{58} \mathrm{OH}_{8} \cdot 6 \mathrm{H}_{2} \mathrm{O}$ & $\mathrm{P} 3$ & 9.767 & & 19.06 & & & \\
\hline & truscottite & $\mathrm{Ca}_{14} \mathrm{Si}_{24^{0}}{ }_{58}^{(\mathrm{OH})_{8}} \cdot 2 \mathrm{H}_{2} \mathrm{O}$ & $P \overline{3}$ & 9.735 & & 18.83 & & & \\
\hline$s_{1} 0 s_{2} \times \bar{s}_{2} \overline{o s}$ & gyrolite & $(\mathrm{Ca}, \mathrm{Na}, \mathrm{D}){ }_{17}(\mathrm{Si}, \mathrm{Al}){ }_{24} \mathrm{O}_{60}{ }^{(\mathrm{OH})} \mathrm{g}_{8} \cdot(14+\mathrm{x}) \mathrm{H}_{2} \mathrm{O}$ & $p^{\bar{\gamma}}$ & 9.74 & 9.74 & 22.40 & $95.7^{\circ}$ & $91.5^{\circ}$ & $120.0^{\circ}$ \\
\hline \multirow{2}{*}{$\operatorname{OS}_{2} \bar{s}_{2}{ }^{0}$} & fedorite & $\mathrm{K}_{2}\left(\mathrm{Ca}_{5} \mathrm{Na}_{2}\right) \mathrm{Si}_{16} \mathrm{O}_{38}(\mathrm{OH}, \mathrm{F})_{2} \cdot \mathrm{H}_{2} \mathrm{O}$ & $\mathrm{P} \overline{1}$ & 9.67 & 9.67 & 12.67 & $102.2^{\circ}$ & $71.2^{\mathrm{c}}$ & $120.0^{\circ}$ \\
\hline & K-phase & $\mathrm{Ca}_{7} \mathrm{Si}_{16} \mathrm{O}_{38}{ }^{(\mathrm{OH})_{2}}$ & $\mathrm{p} \overline{\mathrm{T}}$ & 9.70 & 9.70 & 12.25 & $108.5^{\circ}$ & $78.0^{\circ}$ & $120.0^{\circ}$ \\
\hline$O \mathrm{~S}_{2} \times \bar{S}_{2} \mathrm{O}$ & Z-phase & $\mathrm{Ca}_{9} \mathrm{Si}{ }_{16}{ }^{\mathrm{O}} 40^{(\mathrm{OH})_{2}} \cdot(14+x) \mathrm{H}_{2} \mathrm{O}$ & $?$ & 9.65 & 9.65 & $d_{001}=15.3 \AA$ & A ? & $?$ & $120.0^{\circ}$ \\
\hline
\end{tabular}


is obtained for the Z-phase, in good agreement with the data in Table 6.

The K-phase is a calcium silicate hydrate obtained and studied by Gard et al. (1981). They prepared the compound hydrothermally from calcium oxide and silicic acid in silica-rich mixes at temperatures around $375^{\circ} \mathrm{C}$. The compound was mixed with other phases which almost always included truscottite and truscottite randomly interstratified with gyrolite. The structural scheme reported in Table 5 was proposed and successfully tested with an X-ray powder diffraction pattern by Gard et al. (1981), who obtained for the K-phase the chemical composition $\mathrm{Ca}_{7} \mathrm{Si}_{16} \mathrm{O}_{38}(\mathrm{OH})_{2}$. The natural phase fedorite, $\mathrm{K}_{2}\left(\mathrm{Ca}_{5} \mathrm{Na}_{2}\right) \mathrm{Si}_{16} \mathrm{O}_{38}$ $(\mathrm{OH}, \mathrm{F})_{2} \cdot \mathrm{H}_{2} \mathrm{O}$, develops the same structural scheme as the K-phase (Sokolova et al., 1983), with the introduction of potassium cations and water molecules into the tetrahedral double sheet.

Table 6. Chemical data (from Gard et at., 1975) and unit cell
contents for the Z-phase.
\begin{tabular}{rrrr}
$\mathrm{SiO}_{2}$ & 52.09 & $\mathrm{Si}$ & 15.22 \\
$\mathrm{Al}_{2} \mathrm{O}_{3}$ & 2.26 & $\mathrm{Al}$ & 0.78 \\
$\mathrm{CaO}$ & 27.15 & $\mathrm{Ca}$ & 8.50 \\
$\mathrm{Na}_{2} \mathrm{O}$ & 0.18 & $\mathrm{Na}$ & 0.10 \\
$\mathrm{H}_{2} \mathrm{O}$ & 18.18 & $\mathrm{H}_{2} \mathrm{O}$ & 17.72 \\
\hline
\end{tabular}

The structural schemes of the K-phase and fedorite on one hand, and truscottite and reyerite on the other hand, are similarly related to those of the Z-phase and gyrolite respectively. The minerals mentioned are obtained from the respective phases by splitting the tetrahedral double sheet $\bar{S}_{2} S_{2}$ and inserting the calcium-water sheet $X$ in between.

Both Z-phase and gyrolite crystals show a remarkably similar behaviour on heating: their basal spacings reversibly decrease by nearly $3 \AA$ on heating at 300 and $400^{\circ} \mathrm{C}$ respectively. This decrease may be related to a loss of water molecules in the interlayer sheet, with closing up of the two complex layers facing each other. Moreover both $\mathrm{Z}$-phase and gyrolite are converted to $\alpha-\mathrm{CaSiO}_{3}$ on heating at $700^{\circ} \mathrm{C}$. It seems useful to recall that $\mathrm{X}$-ray examination of heated crystals of reyerite and truscottite (Chalmers et al., 1964) and gyrolite (Mackay and Taylor, 1953) showed that all these compounds convert to $\alpha-\mathrm{CaSiO}_{3}$ and the conversion has a topotactic character, $\alpha-\mathrm{CaSiO}_{3}$ being formed with a marked preferred orientation. The orientation relative to the starting compounds suggests that the continuous calcium octahedral layers remain intact in the course of the transformation.
Finally it seems worthwhile to stress the similarities which exist between the structures of gyrolite and okenite, the latter being often associated with gyrolite in basalts. Both phases are built up by sequences of complex layers and interlayer sheets. In contrast to the $\bar{S}_{2} \bar{O} S_{1} O S_{2}$ layer in gyrolite, the SOCOS layer in okenite (Merlino, 1983) is formed of infinite tetrahedral sheets $S$ characterized by fiveand eight-membered rings, double tetrahedral chains $C$ and double octahedral chains $O$; moreover the interlayer sheets, while similar in composition, are different in structure. Thus the various components differ in the two structures, but are quite closely related, giving a striking resemblance in their general features. In contrast to gyrolite, okenite transforms to $\beta$ - $\mathrm{CaSiO}_{3}$ on heating: the presence of octahedral ribbons in its structure, instead of the octahedral layers in gyrolite, appears as a determining factor in the transformation.

\section{Acknowledgements}

The author is indebted to P. Zanazzi (University of Perugia) for his generous help in intensity data collection, to S. Koritnig (University of Gottingen) and O. V. Petersen (University of Copenhagen) who provided specimens of gyrolite from Bramburg and Qarusait respectively, and to H. F. W. Taylor (University of Aberdeen) for the critical reading of the manuscript and his useful suggestions. The support by 'Centro di studio per la Geologia strutturale e dinamica dell'Appennino', C.N.R., is acknowledged.

\section{References}

Anderson, T. (1851) Phil. Mag. Sec. IV, 1, 111. Assarsson, G. O. (1957) J. Phys. Chem. 61, 473

Cann, J. R. (1965) Mineral. Mag. 35, 1.

Chalmers, R. A., Farmer, V. C., Harker, R. I., Kelly, S., and Taylor, H. F. W. (1964) Ibid. 33, 821.

Christie, W. A. K. (1925) Rec. Geol. Surv. India, 56, 199. Clarke, F. W. (1889) Am. J. Sci. 38, 128.

Cromer, D. T., and Mann, J. B. (1968) Acta Crystallogr. A24, 321.

Dornberger-Schiff, K. (1956) Ibid. 9, 593

-(1966) Lehrgang uber OD-Strukturen. Akademie Verlag. Berlin.

Eberhard, E., and Hamid Rahman, S. (1982) Ref. Diskussiontagung A.G.Kr., Z. Kristallogr. 159, 34.

Flint, E. P., McMurdie, H. F., and Wells, L. S. (1938) J. Res. Nat. Bureau Standards, 21, 617.

Franzini, M., and Leoni, L. (1972) Atti Soc. Tosc. Sc. Nat. Serie A, 79, 7.

Funk, H., and Thilo, E. (1955) Z. anorg. allg. Chem. 278, 237.

Garavelli, C. L., and Vurro, F. (1984) Rend. Soc. It. Min. Petr. 39, 695.

Gard, J. A., Luke, K., and Taylor, H. F. W. (1981) Cem. Concr. Res. 11, 659.

_- Mitsuda, T., and Taylor, H. F. W. (1975) Mineral. Mag. 40, 325. 
Gottardi, G., and Passaglia, E. (1967) Per. Mineral. 36, 1079.

Harker, R. I. (1964) J. Am. Ceram. Soc. 47, 521.

How, O. (1861) Edinb. N. Phil. J. 14, 117.

Hussak, E. (1906) Zentralblatt für Mineralogie 1906, 330.

Istrate, G., and Anton, O. (1985) III Meeting Europ. Un. Geosc., Terra Cognita, 5, 328.

Kobayashi, A., and Kawai, T. (1974) Geosci. Mag. 25, 367.

Kudriashova, V. I. (1958) Dokl. Akad. Nauk. SSSR, 123, 538.

Lachowski, E. E., Murray, L. W., and Taylor, H. F. W. (1979) Mineral. Mag. 43, 333.

Leoni, L., and Saitta, M. (1973) X-ray Spectrom. 3, 74.

Mackay, A. L., and Taylor, H. F. W. (1953) Mineral. Mag. 30, 80 .

Merlino, S. (1972) Nature Phys. Sci. 238, 124.

-_(1983) Am. Mineral. 68, 614.

(1988) Mineral. Mag. 52 (in press).
Meyer, J. W., and Jaunarajs, J. L. (1961) Am. Mineral. 46, 913.

Mizota, T. (1969) J. Jap. Assoc. Min. Petr. \& Econ. Geol. 62, 329 .

Schaller, W. T. (1905) U.S. Geol. Surv. 262, 124

Sokolova, G. V., Kashaev, A. A., Drits, V. A., and Ilyukhin, V. V. (1983) Sov. Phys. Crystallogr. 28(1), 195.

Strunz, H., and Micheelsen, H. (1958) Naturwiss. 45, 515.

Sukheswala, R. N., Avasia, R. K., and Gangopadhyay, M. (1974). Mineral. Mag. 39, 658.

Sweet, J. M. (1961) Ibid. 32, 745.

Taylor, H. F. W. (1962) Proc. 4th Int. Symp. Chem Cement, Washington 1960, 1, 167.

(1964) In The Chemistry of Cements (H. F. W. Taylor, ed.) Vol. I, 204.

[Manuscript received 5 January 1987;

revised 27 May 1987$]$ 